\title{
Conflicts Whether in Relationship, Task or Process does Impact the Team Performance of Adults
}

The Journal of Educational Paradigms

2020, Vol. 02(02) 112-119

(c) Authors

ISSN (Print): 2709-202X

ISSN (Online): 2709-2038

DOI: $10.47609 / 0202012020$

\section{Ayesha zulfqar ${ }^{1}$, Nauheen Syed ${ }^{2}$, Madiha Riaz $^{3}$, Iram Bashir ${ }^{4}$, Sheikh Farhan Ashraf ${ }^{5}$}

\section{Abstract}

This study aims to determine intragroup conflict factors that could be found within teams in an organization, the relationship between intragroup conflict, and team performance, which included relationship conflict, task conflict, and process conflict. SPSS is used to analyze the regression on the proposed model. The data has been collected from the education sector, with the sample size of 150 target population. This study proposed a positive relationship between task conflict, process conflict, and team performance; therefore, a negative relationship was examined for relationship was examined.

Key words: Team performance, Relationship conflict, Task conflict, Process conflict.

Teams can increase an organization's tractability, running complex production processes, and facilitating the related amendment. Also, teams are energetic as they can combine abilities and resources or add the knowledge and inspiration into the work since they come from different backgrounds. This would establish a sustainable, economic advantage, and boost company performance (Grant, 1991; Hamel and Prahalad, 1994).

However, people are hard to work in a team (Campion, Medsker, \& Higgs, 1993; Hare, \& O'Neill, 2000). Further exercise of teams is highly appreciable, and the team-based structure company has become very common (Devine, Clayton, Philips, Dunford, \& Melner, 1999). In teamwork, clash as the disagreement in opinions or unpredictable desires among the parties (Boulding 1963). It would switch the development of faith and admiration between team members (Langfred 2007) and likely damage team efficiency (Jehn, \& Mannix, 2001). The conflict has led to significant problems in teams, and it stays with main issues that will affect the group accomplishment, or even the team performance is affected (Amason, 1996). It is due to the persons of the team frequently having differences in personal phases (De Dreu, 2008), a conflict could come out with a negative significance toward team efficiency. DeDreu \& Van de Vliert, (1997); Jehn, (1995); Simons and Peterson, (2000) task conflict, indicating "conflicts about the procedures, division of resources, policies and judgment form of conflict facilitate the developing of different concepts and debate among team members. Viewpoints enhance dialogue and thus lead to improved team creativeness (De Dreu, \& Weingart, 2003; De Dreu, 2006).

Task conflict is significantly related to the quality of the decision quality (Amason, 1996; Parayitam, \& Dooley 2007). Task conflict such as differences about the matters and the suitable selections of the different strategies and verdict changes about the decision (De Dreu 2006). It is only favorable to create inspired concepts by helping different types of thoughts and material discussion or reconsidering the challenge position and growth period (De Dreu, 2006; De Dreu, \& West, 2001; Shalley, \& Gilson, 2004). It may decrease the level of trust. And lastly, it could damage the team performance (Costa 2003; Greer, \& Jehn 2007).

The study first posits a direct association between intragroup conflicts and team performance in university employees. Then, to provide a richer explanation of this relationship, the study determines types of intragroup conflict that could be found within teams in an organization. Extending the model to this analysis level should be a significant contribution to the literature because only a handful of empirical studies have looked at the effect of intragroup conflicts on team performance. This study's primary objectives are (1) Explore the perception of the team and team performance, conflict, and types of conflicts, and organizational performance of Pakistani universities' employees; (2) Explore the relationship between intragroup conflict and team performance.

\section{Literature Review}

Team and Team Performance

Organizations are placing greater belief on team-based arrangements for quality improvement, efficiency, customer care, problem-solving, and the understanding at a job for their members (Guzzo, 1995). It was also said that organizations are more motivated to select and give the responsibility for complex decision making to teams instead of individuals (Mesmer-Magnus \& DeChurch, 2009). Team-based environments can provide improvement in terms of a highly coordinated work-life (Jones, 2004).

In a group, participants distributed the similar intention of achieving a mutual objective and shared its diversity of possessions, ideas, and knowledge (Townsley, 2009), participants distribute the similar intention of achieving a mutual purpose. Besides, the author also revealed that a benefit a group has over a

\footnotetext{
${ }^{12}$ Department of Business Administration, Government College Women university, Faisalabad, Pakistan,

3 Department of Economics. Ghazi University, Dera Ghazi Khan, Corresponding author Email: nausheen.dr@gmail.com.

${ }^{4}$ Lyallpur Business School, Government College University, Faisalabad.

${ }^{5}$ School of Management Science, Jiangsu University, Zhenjiang, China.
} 
person is its diversity of possessions, ideas, and knowledge. Mesmer-Magnus and DeChurch (2009) also suggested that utilizing teams could expand the pool of information, which is essential in providing higher quality resolutions than what could be offered by individuals (Sikes, Gulbro, \& Shonesy, 2010). As the team's unique structure, possibly, people functioning together apply diverse individual rules and explanations to their tasks (Keyton \& Beck, 2008). group persons should be capable of controlling their disagreements helpfully to make their groups successful (De Dreu, Weingart \& Kwon, 2000; Jehn \& Mannix, 2001).

\section{Team Performance}

There are healthy and depressing relationships among relationship disagreement, group presentation, and group member happiness (De Dreu, \& Weingart, 2003). Only, when no additional resource than the group itself was existing, we trusted the group member's evaluations of their presentation. (Duffy, Shaw, \& Stark, 2000; Janssen et al., 1999; Jehn et al., 1999). But disagreement may have positive consequences under very explicit circumstances in the group. Communication perspective feasible or customary interface is much troubling or fruitful to the effects of intragroup conflict on group presentation (Martínez-Moreno, et al., 2009). The communication medium may play a significant moderating character in the relationship between intragroup conflict and group presentation (Guzzo, \& Dickson, 1996).

Face to face group presentation is also enhanced by the work disagreement and procedure clash every job (Hassall, 2009). Further, group knowledge is a procedure to improve their performances (Van Woerkom \& Croon, 2009). Where group affiliates are mutually dependent for several common reasons, collaborate, and are expected to work jointly in the coming days (Bradley et al., 2003), groups need to concentrate on their knowledge behavior (Kratzer et al., 2004). In the group procedure towards team and group presentation, social arrangements, or societal resources have much worth.

There is considerable relation among collective resources and group presentations. Moreover, societal resources (i.e., relational, emotional, and structural) and their relationship influence group presentation (Clopton, 2011). Legislative ability positively affects group presentation by encouraging the superiority of group communication (Liu, Wang, \& Cao, 2011), and legislative ability is found to be severe abilities that managers need to do hard work to improve this skill. The group empowerment can enlarge the intragroup conflict and knowledge sharing in groups (Leelawong et al., 2016). Team empowerment produces a diverse group presentation over culture due to the moderating consequences of authority remoteness. Socialism and group empowerment efficiency depend on the civilization background that the group works inside Mitchell et al. (2011). Cooperative group promise help as important possibilities for the correlation among the group legislative ability and group presentation (Semrau, Steigenberger, et al., 2017).

\section{Conflict}

Conflict is the alertness on the events involved in dissimilarities in views, mismatched desires, or contradictory wishes (Boulding, 1963). Disagreement is said to be almost positive to arise in work teams. When persons meet in workgroups, there are dissimilarities in groups of authority, principles and attitudes, and societal aspects - all payments to the formation of disagreement (United Nations, 2002). Rahim (2002) suggested that conflict may occur in six conditions, a party holds behavioral preferences, it also owns feelings, skills, principles, and objectives that are significant to direct his or her actions. A conflict could be useful, so that it may still be suggested to encourage competition (John, 1994; Van de Vliert\& De Dreu, 1994; Amason, 1996; Schulz-Hardt, Mayer, \& Frey, 2002).

\section{Relationship Conflict}

Relationship conflict is well-defined as knowledge of disagreements. It contains emotional components, friction, emotion, and strain related to stress, enmity, and irritation amongst participants in a team (De Dreu \& Weingart, 2003). The frustration occurs among the group members and feelings dissimilar to the job (Chou, \& Yeh, 2007), and dislike between team participants and emotions, i.e., obstruction, bother, and frustration (Jehn \& Mannix, 2001). Relationship conflicts often reported are regarding clothing preferences, hobbies, societal proceedings, rumor, and political observations (Jehn, 1997).

The negative relationship among association and detestation resulting in conflict influences group participants' performance and satisfaction. Negative answers relationship conflict, productivity, such as anxiety and depression, dropping their efficiency, and tumbling team performance (Evan, 1965; Gladstein, 1984; Wall and Nolan, 1986). For that reason, participants attention on decreasing fears, as well as trying to construct unity despite working on the mission, increasing power, and these limit the information processing capacity of the team (Simons and Peterson, 2000), relationship conflicts reduce shared considerate and goodwill (Deutsch, 1969).

This depends on past research as relationship conflict is harmful to the growth of planned synchronization (Knight, Pearce, Smith, Olian, Sims, Smith \& Flood, 1999), to personal and team presentation participant pleasure (Jehn, 1995). Time is frequently used upon the team's relational features, not on technological and managerial works (Evan, 1965). Emotional factors like mood, trust issues, values, and costs play an important role in teamwork failure by relationship conflicts (Ismail, Richard, \& Taylor, 2012). Relationship conflict causes the group performance (Wickramasinghe, \& Nandula, 2015). There are significant relationship disagreements between workers in case of their job presentation, income purposes, and background performance (Shaukat, Yousaf, \& Sanders, 2017).

The group participants' malicious behavior increases the relationship conflicts (Benitez, Medina, \&Munduate, 2018), as well as found that the relationship disagreement is a broad foundation of the pressure at a job (Giebels, \& Janssen, 2005; Ilies et al., 2011). It also showed that the relationship conflict increases the expressive fatigue practices (Dijkstra et al., 2005; Dijkstra et al., 2009). Moreover, found that conflict is unfavorable to team efficiency and satisfaction (Gladstein, 1984; Saavedra, Earley, \& Van Dyne, 1993; Wall \& Nolan, 1986). This is because conflict produces pressure, anger, and obstruction that might cause participants to effort negatively efficiently by everyone. People do 
not trust on teamwork as well. All of this reaction would reduce the satisfaction of workers and disturbs them from performing the task excellently.

However, not all conflict is terrible groups can create improved results since members provide different knowledge and judgment (Frey, 2002). Team performance has become vital within modern organizations (DeShon et al., 2004; Kimura, 2014). We must be trusted on grouping. Groups typically are predictable toward recovery governmental efficiency, so some responsibilities are there to group works. But the tension between team members is due to real or apparent differences (De Dreu and Weingart, 2002). The conflict on team performance is exceedingly unreliable (Hempel et al.,2009; KirchmeyerandCohen,1992; Tekleab et al., 2009; Tjosvold et al., 2003), and conflict within teams is troubled with task and relationship concerns (Amason \& Schweiger, 1997; Cosier \& Rose, 1977; Guetzkow \& Gyr, 1954; Jehn, 1997; Kabanoff, 1991).

In effect, management conflict must be revealed to improve team performance (Behfar et al., 2008; Somech et al., 2009; Tekleab et al., 2009; Tjosvold et al., 2003). The task is a conflict, so the results of the process from the burden among the team members due to real and apparent dissimilarities (De Dreu, Harinck, \& Van Vianen, 1999; Thomas, 1992; Wall \& Callister, 1995. It understood that human resource management practices improving by performances (Delaney, \& Huselid, 1996), and teams must come to be vital structures of the company efficiency above the previous years (Wilson et al., 2007). When the people are responsible for the work, then the chances for a great team performance are acceptable (Wageman et al., 2005; Hackman, 2002; Kozlowski \& Bell, 2003; West et al., 1998). Relationship conflict outcomes are about the clashes between the individual and how to cooperate with the other person (Choi and Sy, 2010; Jehn et al., 1999).

Relationship conflict weakens the team performance (Furumo, 2009; Jehn and Mannix, 2001) happens because of the disagreements between the members of the team (Furumo, 2009; Hinds, \& Bailey, 2003; Jehn, \& Mannix, 2001), and damaging reactions, e.g., anxiety and dislike and it decreases the efficiency of team performance. The relationship conflict is relatable to the task conflict (Simons and Peterson 2000; Tidd et al., 2004; Mooney et al., 2007; \& Gamero et al., 2008). Instead, unselfishness has been suggested as a significant blockage of the relationship conflict (Eddleston, \& Kellermanns, 2007; Kellermanns, \& Eddleston, 2004). Relationship conflict might block the positive actions (Kellermanns and Eddleston 2004) that happen after the dyad persons practice the interactive inconsistencies.

The members' relationship is fill through the toughness and roughness (Jehn and Mannix, 2001), which contribute damagingly to the workers. It reduces the belief in their supervisors (Kacmar et al., 2012). Have adverse outcomes of the no racial relationships (Duguid et al., 2012; Lewis and Sherman, 2010; Simons et al., 2007). Relationship conflict can also influence the manager. It depends on the incidence of communication (Becerra, \& Gupta, 2003) raises disappointment at the workplace (Dijkstra et al., 2009; Wright and Loving, 2011). It negatively affects worker fitness and the group presentation (Seong and Choi, 2014), Meier et al., 2014). Create bad feelings, the absenteeism of the workers, and the workers (De Wit et al., 2012), it is a source of emotional frustration and harassment (Leon-Pérez et.al., 2014).

\section{Task Conflict}

Task disagreement is known as conflicts concerning the division of assets policies and processes, and interpretation and data (De Dreu \& Weingart, 2003). Task disagreement is also said to be the difference between the team participants' opinions and ideas concerning the job being achieved (Chou \&Yeh, 2007). Task disagreement more possibly occurs when team members came across conflict regarding the work they do, differences of opinions, divergences regarding work being done, and common conflict on ideas (Berdensky et al. 2010). When disagreement is not present then, it is suggested that reasonable altitudes of task Simons and Peterson (2000) disagreement are helpful, because they encourage discussion of thoughts that assist teams in carrying out good (Jehn, 1995). High levels of task conflict cause negative emotional states such as frustration, obstruction, tension, bitterness, and sadness among team participants (Jehn, 1995; Curseu, Boros \& Oerlemans, 2012).

Not only that, but task conflict is also seen as is the predecessor of relationship conflict as well (Curseu \& Schruijer, 2010; Greer, Jehn\&Mannix, 2008). Task disagreements obstruct group performance, and member satisfaction and (De Dreu \& Weingart 2003; and De Dreu 2006). On the other hand, positive relationships exist between task and connection disagreement (Medina, Dorado, Munduate, Martinez and Cisneros 2002). That contributes toward the ground association between job and relationship disagreement in groups (Ayoko, Callan \& Hartel, 2008; Nair, 2008; Speakman $\&$ Ryals, 2010). An assurance on agreement plays a moderating part between seeking behavior of task conflict and interpersonal conflicts (Parayitam, Olson, \& Bao, 2010).

Task disagreement describes the association among the band customs and target to be quit (McMillan et al., 2012) because irregular observations of task conflicts impact the expected relationship with the partner (Jehn, et al., 2015). Task disagreement had an overturned curved association with inventive thought creation, and task reflexivity partly mediated this association (Chen, et al., 2019). Task disagreement is straight connected to group inventiveness (Lee, et al., 2019).

\section{Process Conflict}

Process conflict is a practically unique and significant kind of disagreement that is diverse after job conflict and association disagreement, and that has unique consequences on group outcomes (Jehn, Greer, Levine, \& Szulanski, 2008). Process disagreement is defined as disagreements regarding the strategy and allocation concerns such as how task achievement progress in the job component. In the end, it will influence the performance of the whole group (Jehn 1997). Jehn et al. (2008) find that all the three forms of conflict that contain relationships, a task, and process conflict will decrease positive developing states (attitudes, values, and thought held by the member) within-group.

The finding is more supported by (Greer et al., 2011), identifying that process conflict is one type of intragroup conflict that negatively affects team performance. Process disagreement 
individually and diverse from the task disagreement (Jehn 1997). Research showed that the inverse effects do correctly mediate the association among process disagreement and group presentation (Greer, \& John, 2007). Process conflict negatively affected team performance Behfar, et al., 2011). Disagreement situation managed limited time, resolving the unfavorable attitude and behavior towards process conflict (Alok, et al., 2015).

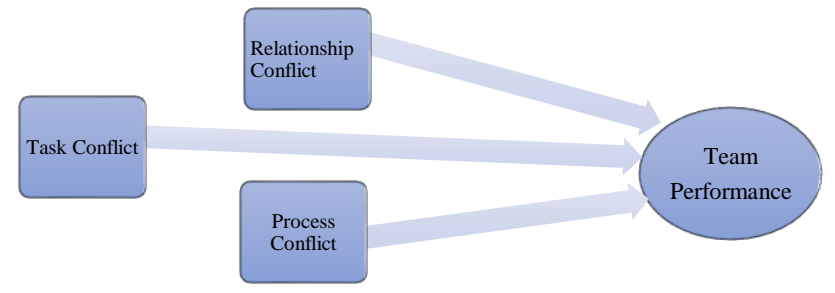

Figure 1: Conceptual model

H1: There is a negative affet between relationship conflict and team performance.

H2: There is a positive affect between task conflict and team performance.

H3: There is a negative affect between process conflict and team performance.

\section{Research Methodology}

The sample size of this study was initially targeted to 150 from different areas. The analytical tool of this study used to analyze was the SPSS software and the regression test analysis. Data has been collected from the education sector, investigating university students from Faisalabad, and students were taken from four universities. NFC Institute of Engineering and Fertilizer Research, University of Sargodha, Lyallpur Campus, Faisalabad, Government College Women University, and the University of Central Punjab, Faisalabad Campus selected as the target population.

The sample size was 150 , and questionnaires were distributed to collect the data, and one hundred fifty respondents were accessed to fill in the questionnaires. These respondents are the senior positions and students of the universities. In the education sector, most of them carry out their work in a project form so that they will need to corporate with each other and even other teams. Few of those were reporting missing values, which were discarded later. In the last, 200 questionnaires were found useful, yielding a response rate of $85.67 \%$. It took more than three and a half months to reach the said response rate (Min \& Mentzer, 2004). NonProbability sampling, more precisely judgmental sampling, and convenient sampling were executed in the pilot study.

\section{Data Analysis}

The descriptive data analysis is analyzed by utilizing the SPSS (adaptation 21.00) program to achieve the data and close if the data met the basic assumption required to conduct multivariate techniques. Following descriptive analysis, a measurement scale is used in the questionnaire to catch each model construct's meaning and is measured by reliability and validity. The 'Cronbach's alpha' is utilized to measure the scale reliability, which shows the consistency of responses across each item within the scale. However, "Inter total correlation" is used to assess the degree to which a item belongs to its scale.
Table 1: Model Statistics

\begin{tabular}{ccccc}
\hline Model & $\mathbf{R}$ & $\mathbf{R}^{\mathbf{2}}$ & Adjusted $\mathbf{R}^{\mathbf{2}}$ & $\begin{array}{l}\text { Std. Error of the } \\
\text { Estimate }\end{array}$ \\
1 & $.501^{\mathrm{a}}$ & .251 & .235 & .95340 \\
\hline
\end{tabular}

a. Predictors: (Constant), process conflict, Relationship conflict, Task conflict The table of model summary displays the result of linear regression analysis on test $\mathrm{R}$, which is $0.501(\mathrm{R}=50.1 \%)$, represent the positive correlation amongst the independent and the dependent variable in the result. While the $\mathrm{R}$ square test is 0.251 ( $\mathrm{R}$ square = $25.1 \%$ ), represent the amount of variation predictable in team performance from the result above.

Table 2: ANOVA Statistics

\begin{tabular}{lccccc}
\hline Model & $\begin{array}{c}\text { Sum of } \\
\text { Squares }\end{array}$ & Df & Mean Square & F & Sig. \\
\hline Regression & 44.400 & 3 & 14.800 & 16.282 & .000 \\
Residual & 132.711 & 146 & .909 & & \\
Total & 177.111 & 149 & & & \\
\hline a. team performance & & & \\
b. Predictors: (Constant), process conflict, Relationship conflict, Task conflict & \\
\hline
\end{tabular}

F-statistics is 16.282, and the value of the $\mathrm{p}$ is 0 , so that means the value of the $p$ is $<0.05$ level of significance. This result indicated the three independent variables do explain significantly about a variation of the team performance. Therefore, it displays that the researcher model is significant. The interpretation is good enough to define all the predictors' independent variables that can be used to predict the dependent variable.

Table 3: Coefficients

\begin{tabular}{llllll}
\hline Model & \multicolumn{2}{l}{$\begin{array}{l}\text { Unstandardized } \\
\text { Coefficients }\end{array}$} & $\begin{array}{l}\text { Standardized } \\
\text { Coefficients }\end{array}$ & T & Sig. \\
\cline { 2 - 5 } & $\mathrm{B}$ & $\begin{array}{l}\text { Std. } \\
\text { Error }\end{array}$ & Beta & & \\
\hline (Constant) & 1.620 & .406 & & 3.99 & .000 \\
Relationship Conflict & -.278 & .104 & -.202 & -2.68 & .008 \\
Task conflict & .546 & .115 & .375 & 4.73 & .000 \\
Process Confits & .331 & .100 & .254 & 3.30 & .001 \\
\hline
\end{tabular}

Table shows the Beta $(\beta)$ values and $p$-value under the coefficients table, which can measure the importance of independent variable (relationship conflict, task conflict, process conflict) towards the team performance that is the dependent variable. The result shows the task conflict has the largest beta value, $\beta=0.375$, which means it has the most significant relationship towards team performance. About the stage of significance, its p-value is 0.000 that less than 0.05 . Hence, hypothesis 2 is supported that shows the positive relationship between the task conflict and team performance. The second rank process conflict with a beta value of 0.254 and a pvalue of 0.001 that $<0.05$.

However, it has passed the level of significance; hence, it also supported a positive connection between process conflict and team performance. Lastly, relationship conflict has a beta value of 0.202 , and the value of the $p$ is 0.008 that ranked as last place, third. Since the p-value is fulfilling requirements under the stage of significance, hypothesis 1 is supported, showing the negative relationship among the independent (relationship conflict) and dependent (team performance) variables. All the variables fulfill the requirement of $p<0.05$, it can be concluded from the column headed ' $\mathrm{B}$ ' under the category of unstandardized coefficients.

\section{Conclusion}

This research aimed to discover "the relationship of intragroup conflict with the team performance." Independent variables such as relationship conflict, task conflict, and process conflictdependent variable team performance are utilized to investigate 
the relationship empirically. There is a significant negative connection between the relationship conflict and team performance. According to Berdensky et al. (2010), relationship conflict is most probable to occur while there is emotional stress between the group persons, frequent personal resistance betweengroup persons, and when character clashes are evident (Simons, \& Peterson, 2000). Since, the relationship conflict is not related to the task conflict. Group members often experience intense negative feelings, misunderstandings or stereotypes, ineffective communication or miscommunication, or tedious undesirable actions. These situations could amount to destructive conflict, and team performance will be affected.

Secondly, the result demonstrates that there is a significant positive connection. Simons and Peterson (2000), the teams who experienced the task conflict manage to construct better selections related to the decisions, because such conflicts motivate a better emotional understanding of the trouble being considered. Besides, task conflict can help make better decision-making results and team efficiency by enhancing decision excellence by including the devil's advocacy characters and productive critique (Cosier and Rose, 1977; Schweiger, Sandberg \& Rechner, 1989; Amason, 1996).

Therefore, the result is proving that task conflict can positively affect the team performance. Thirdly, results are against our hypothesis created; hence, some authors have different ideas about this conflict that can support and assume this finding. Watson, Johson, and Merritt (1998), the team process is an essential element in developing team synergy. Other cultural differences mainly cause this conflict; however, it might affect the quality of the teams' learning procedure and results.

These authors also said that individual differences might significantly add the group's process tasks. Watson, Danielle, Jose, and Nancy (2008) identify that Mexican groups verified lower efficient group procedures with more conflict. The entire research show that process conflict carried from the team is considered some positive relations inside. Therefore, it can be assumed that the education Faisalabad individual and cultural differences to fix this field of conflict. While from these changes, it can be assuming that the thinking sector had started using process conflict to create team cooperation and teams' learning outcomes. Indeed, we have carried out the result with a positive relation amongst process conflict and the team performance.

\section{References}

Alok, S., Raveendran, J., \&Jha, A. K. (2015). Process conflict management among Indian software employees: Prediction of conflict handling intention in fast changing global IT market using the theory of planned behaviour. Journal of Indian Business Research, 7(2), 140-160.

Amason, A. C. (1996). Distinguishing the effects of functional and dysfunctional conflict on strategic decision making: Resolving a paradox for top management teams. Academy of Management Journal, 39(1), 123-148.

Amason, A. C., \& Schweiger, D. M. (1997). The effects of conflict on strategic decision-making effectiveness and organizational. Using conflict in organizations, 101.
Ayoko, O. B., Callan, V. J., \&Härtel, C. E. (2008). The influence of team emotional intelligence climate on conflict and team members' reactions to conflict. Small Group Research, 39(2), 121-149.

Behfar, K. J., Peterson, R. S., Mannix, E. A., \&Trochim, W. M. (2008). The critical role of conflict resolution in teams: A close look at the links between conflict type, conflict management strategies, and team outcomes. Journal of Applied Psychology, 93(1), 170.

Benitez, M., Medina, F. J., \&Munduate, L. (2018). Buffering relationship conflict consequences in teams working in real organizations. International Journal of Conflict Management, 29(2), 279-297.

Bendersky, C., Behfar, K., Weingart, L. R., Todorova, G., Bear, J., \&Jehn, K. A. (2010, June). Revisiting the dimensions of intragroup conflict: Theoretical and psychometric construct refinement. In IACM 23rd Annual Conference Paper (pp. 1103).

Boulding, K. E. (1963). Towards a pure theory of threat systems. The American Economic Review, 53(2), 424-434.

Bradley, J., White, B. J., \& Mennecke, B. E. (2003). Teams and tasks: A temporal framework for the effects of interpersonal interventions on team performance. Small Group Research, 34(3), 353-387.

Campion, M. A., Medsker, G. J., \& Higgs, A. C. (1993). Relations between work group characteristics and effectiveness: Implications for designing effective work groups. Personnel psychology, 46(4), 823-847.

Chou, H. W., \&Yeh, Y. J. (2007). Conflict, conflict management, and performance in ERP teams. Social Behavior and Personality: An International Journal, 35(8), 1035-1048.

Choi, J. N., \& Sy, T. (2010). Group-level organizational citizenship behavior: Effects of demographic faultlines and conflict in small work groups. Journal of Organizational Behavior, 31(7), 1032-1054.

Clopton, A. W. (2011). Social capital and team performance. Team Performance Management: An International Journal, 17(7/8), 369-381.

Coser, L. A. (1956). 1956 The Functions of Social Conflict. New York: Free Press.

Cosier, R. A., \& Rose, G. L. (1977). Cognitive conflict and goal conflict effects on task performance. Organizational Behavior and Human Performance, 19(2), 378-391.

Costa, A. C. (2003). Work team trust and effectiveness. Personnel Review, 32(5), 605-622.

Curşeu, P. L., \&Schruijer, S. G. (2010). Does conflict shatter trust or does trust obliterate conflict? Revisiting the relationships between team diversity, conflict, and trust. Group Dynamics: Theory, Research, and Practice, 14(1), 66.

Deutsch, M. (1969). Conflicts: Productive and destructive. Journal of social issues, 25(1), 7-42.

Deutsch, M. (1973). 77ie resolution of conflict: Constructive and destructive processes.

De Dreu, C.K.W. \& Van de Vliert, E. (Eds) (1997). Using conflict in organizations, Sage, London. 
Devine, D. J., Clayton, L. D., Philips, J. L., Dunford, B. B., \&Melner, S. B. (1999). Teams in organizations: Prevalence, characteristics, and effectiveness. Small group research, 30(6), 678-711.

Delaney, J. T., \& Huselid, M. A. (1996). The impact of human resource management practices on perceptions of organizational performance. Academy of Management Journal,39(4), 949969.

De Dreu, C. K., Weingart, L. R., \& Kwon, S. (2000). Influence of social motives on integrative negotiation: a meta-analytic review and test of two theories. Journal of Personality and Social Psychology, 78(5), 889.

De Dreu, C. K., \& West, M. A. (2001). Minority dissent and team innovation: The importance of participation in decision making. Journal of Applied Psychology, 86(6), 1191.

De Dreu, C. K., \&Weingart, L. R. (2003). Task versus relationship conflict, team performance, and team member satisfaction: a meta-analysis. Journal of Applied Psychology, 88(4), 741.

De Dreu, C. K., \& Weingart, L. R. (2003).A contingency theory of task conflict and performance in groups and organizational teams. International Handbook of Organizational Teamwork and Cooperative Working, 88(4), 151-166.

DeShon, R. P., Kozlowski, S. W., Schmidt, A. M., Milner, K. R., \&Wiechmann, D. (2004). A multiple-goal, multilevel model of feedback effects on the regulation of individual and team performance. Journal of Applied Psychology, 89(6), 1035.

Dijkstra, M. T., van Dierendonck, D., \& Evers, A. (2005). Responding to conflict at work and individual well-being: The mediating role of flight behaviour and feelings of helplessness. European Journal of Work and Organizational Psychology, 14(2), 119-135.

De Dreu, C. K. (2006). When too little or too much hurts: Evidence for a curvilinear relationship between task conflict and innovation in teams. Journal of Management, 32(1), 83-107.

De Dreu, C. K. (2008). The virtue and vice of workplace conflict: Food for (pessimistic) thought. Journal of Organizational Behavior: The International Journal of Industrial, Occupational and Organizational Psychology and Behavior, 29(1), 5-18.

Dijkstra, M. T., De Dreu, C. K., Evers, A., \& van Dierendonck, D. (2009). Passive responses to interpersonal conflict at work amplify employee strain. European Journal of Work and Organizational Psychology, 18(4), 405-423.

De Wit, F. R., Greer, L. L., \&Jehn, K. A. (2012). The paradox of intragroup conflict: a meta-analysis. Journal of Applied Psychology, 97(2), 360.

Eddleston, K. A., \&Kellermanns, F. W. (2007). Destructive and productive family relationships: A stewardship theory perspective. Journal of Business Venturing, 22(4), 545-565.

Evan W (1965). Conflict and performance in $R \& D$ organizations.IndManag Rev 7, pp.37-46

Furumo, K. (2009). The impact of conflict and conflict management style on deadbeats and deserters in virtual teams. Journal of Computer Information Systems, 49(4), 66-73.

Giebels, E., \& Janssen, O. (2005). Conflict stress and reduced well-being at work: The buffering effect of third-party help. European Journal of Work and Organizational Psychology, 14(2), 137-155.

Gladstein, D. L. (1984). Groups in context: A model of task group effectiveness. Administrative Science Quarterly, 499-517.

Greer, L. L., Jehn, K. A., \&Mannix, E. A. (2008). Conflict transformation: A longitudinal investigation of the relationships between different types of intragroup conflict and the moderating role of conflict resolution. Small Group Research, 39(3), 278-302.

Greer, L. L., \& Jehn, K. A. (2007). Chapter 2 the pivotal role of negative affect in understanding the effects of process conflict on group performance. In Affect and Groups (pp. 21-43). Emerald Group Publishing Limited.

Guetzkow, H., \&Gyr, J. (1954). An analysis of conflict in decisionmaking groups. Human Relations, 7(3), 367-382.

Guzzo, R. A. (1995). Introduction: at the intersection of team effectiveness and decision making. In R. A. Guzzo\& E. Salas (Eds.), Team effectiveness and decision making in organizations (pp. 1-8). San Francisco, CA: JosseyBass.

Guzzo, R. A., \& Dickson, M. W. (1996). Teams in organizations: Recent research on performance and effectiveness. Annual Review of Psychology, 47(1), 307-338.

Guetzkow, H., \&Gyr, J. (1954). An analysis of conflict in decisionmaking groups. Human relations, 7(3), 367-382.

Hare, L. R., \& O’Neill, K. (2000). Effectiveness and efficiency in small academic peer groups: A case study. Small Group Research, 31(1), 24-53.

Hackman, J. R., \& Hackman, R. J. (2002). Leading teams: Setting the stage for great performances. Harvard Business Press.

Hassall, S. L. (2009). The relationship between communication and team performance: testing moderators and identifying communication profiles in established work teams (Doctoral dissertation, Queensland University of Technology).

Hempel, P. S., Zhang, Z. X., \&Tjosvold, D. (2009). Conflict management between and within teams for trusting relationships and performance in China. Journal of Organizational Behavior: The International Journal of Industrial, Occupational and Organizational Psychology and Behavior, 30(1), 41-65.

Hinds, P. J., \& Bailey, D. E. (2003). Out of sight, out of sync: Understanding conflict in distributed teams. Organization science, 14(6), 615-632.

Ilies, R., Johnson, M. D., Judge, T. A., \& Keeney, J. (2011). A within-individual study of interpersonal conflict as a work stressor: Dispositional and situational moderators. Journal of Organizational Behavior, 32(1), 44-64.

Ismail, K. M., Richard, O. C., \& Taylor, E. C. (2012). Relationship conflict in supervisor-subordinate dyads: a subordinate perspective. International Journal of Conflict Management, 23(2), 192-218.

Janssen, O., Van De Vliert, E., \&Veenstra, C. (1999). How task and person conflict shape the role of positive interdependence in management teams. Journal of Management, 25(2), 117-141.

Jehn, K. A., \& Mannix, E. A. (2001). The dynamic nature of conflict: A longitudinal study of intragroup conflict and group performance. Academy of Management Journal,44(2), 238251. 
Jehn, K. A. (1995). A multimethod examination of the benefits and detriments of intragroup conflict. Administrative Science Quarterly, 256-282.

Jehn, K. A. (1997). Affective and cognitive conflict in work groups: Increasing performance through value-based intragroup conflict. Using conflict in organizations, 87100.

Jehn, K. A., De Wit, F. R., Barreto, M., \& Rink, F. (2015). Task conflict asymmetries: effects on expectations and performance. International Journal of Conflict Management, 26(2), 172-191.

Jones, G. R. (2004). Organizational theory, design, and change (4th ed.). Upper Saddle River: Prentice Hall.

Kabanoff, B. (1991). Equity, equality, power, and conflict. Academy of Management Review, 16(2), 416-441.

Kacmar, K. M., Bachrach, D. G., Harris, K. J., \& Noble, D. (2012). Exploring the role of supervisor trust in the associations between multiple sources of relationship conflict and organizational citizenship behavior. The Leadership Quarterly, 23(1), 43-54.

Kellermanns, F. W., \& Eddleston, K. A. (2004). Feuding families: When conflict does a family firm good. Entrepreneurship theory and Practice, 28(3), 209-228.

Keyton, J., \& Beck, S. J. (2008). Team attributes, processes, and values: a pedagogical framework. Business Communication Quarterly, 71(4), 488-504.

Kimura, H. (2014). U.S. Patent No. 8,681,077. Washington, DC: U.S. Patent and Trademark Office.

Kirchmeyer, C., \& Cohen, A. (1992). Multicultural groups: Their performance and reactions with constructive conflict. Group \& Organization Management, 17(2), 153-170.

Langfred, C. W. (2007). The downside of self-management: A longitudinal study of the effects tf conflict on trust, autonomy, and task interdependence in self-managing teams. Academy of Management Journal, 50(4), 885-900.

Leon-Perez, J. M., Notelaers, G., Arenas, A., Munduate, L., \& Medina, F. J. (2014). Identifying victims of workplace bullying by integrating traditional estimation approaches into a latent class cluster model. Journal of Interpersonal Violence, 29(7), 1155-1177.

Lee, E. K., Avgar, A. C., Park, W. W., \& Choi, D. (2019). The dual effects of task conflict on team creativity: Focusing on the role of team-focused transformational leadership. International Journal of Conflict Management, 30(1), 132-154.

Liu, J., Wang, W., \& Cao, K. P. (2011). Leader political skill and team performance: a moderated mediation model. Nankai Business Review International, 2(1), 5-22.

Martínez-Moreno, E., González-Navarro, P., Zornoza, A., \& Ripoll, P. (2009). Relationship, task and process conflicts on team performance: The moderating role of communication media. International Journal of Conflict Management, 20(3), 251-268.

McMillan, A., Chen, H., Richard, O. C., \&Bhuian, S. N. (2012). A mediation model of task conflict in vertical dyads: Linking organizational culture, subordinate values, and subordinate outcomes. International Journal of Conflict Management, 23(3), 307-332.
Meier, L. L., Semmer, N. K., \& Gross, S. (2014). The effect of conflict at work on well-being: Depressive symptoms as a vulnerability factor. Work \& Stress, 28(1), 31-48.

Mesmer-Magnus, J. R., \&DeChurch, L. A. (2009). Information sharing and team performance: A meta-analysis. Journal of Applied Psychology, 94(2), 535.

Medina, F. J., Dorado, M. A., Munduate, L., Martinez, I., \& Cisneros, I. F. (January 2002). Types of conflict and personal and organizational consequences.Submitted to the 15th Annual Conference of the International Association for Conflict Management, in Utah.

Mitchell, R., Boyle, B., \& Nicholas, S. (2011). Cross-cultural group performance. The Learning Organization, 18(2), 94-101.

Mooney, A. C., Holahan, P. J., \& Amason, A. C. (2007). Don't take it personally: Exploring cognitive conflict as a mediator of affective conflict. Journal of management studies, 44(5), 733758.

Nair, N. (2008). Towards understanding the role of emotions in conflict: a review and future directions. International Journal of Conflict Management, 19(4), 359-381.

Parayitam, S., \& Dooley, R. S. (2007). The relationship between conflict and decision outcomes: Moderating effects of cognitive-and affect-based trust in strategic decision-making teams. International Journal of Conflict Management, 18(1), 42-73.

Parayitam, S., Olson, B. J., \&Bao, Y. (2010).Task conflict, relationship conflict and agreement-seeking behavior in Chinese top management teams. International Journal of Conflict Management, 21(1), 94-116.

Rahim, M. A. (2002). Toward a theory of managing organizational conflict. The International Journal of Conflict Management, 13(3), 206-235.

Saavedra, R., Earley, P. C., \& Van Dyne, L. (1993). Complex interdependence in task-performing groups. Journal of Applied Psychology, 78(1), 61.

Schulz-Hardt, S., Jochims, M., \& Frey, D. (2002). Productive conflict in group decision making: Genuine and contrived dissent as strategies to counteract biased information seeking. Organizational Behavior and Human Decision Processes, 88(2), 563-586.

Schweiger, D. M., Sandberg, W. R., \&Rechner, P. L. (1989). Experiential effects of dialectical inquiry, devil's advocacy and consensus approaches to strategic decision making. Academy of Management Journal, 32(4), 745-772.

Seong, J. Y., \& Choi, J. N. (2014). Effects of group-level fit on group conflict and performance: The initiating role of leader positive affect. Group \& Organization Management, 39(2), 190-212.

Semrau, T., Steigenberger, N., \& Wilhelm, H. (2017). Team political skill and team performance. Journal of Managerial Psychology, 32(3), 239-253.

Shaukat, R., Yousaf, A., \& Sanders, K. (2017). Examining the linkages between relationship conflict, performance and turnover intentions: Role of job burnout as a mediator. International Journal of Conflict Management, 28(1), $4-23$. 
Shalley, C. E., \& Gilson, L. L. (2004). What leaders need to know: A review of social and contextual factors that can foster or hinder creativity. The Leadership Quarterly, 15(1), 33-53.

Simons, T. L., \& Peterson, R. S. (2000). Task conflict and relationship conflict in top management teams: The pivotal role of intragroup trust. Journal of Applied Psychology, 85(1), 102.

Simons, T., Friedman, R., Liu, L. A., \& McLean Parks, J. (2007). Racial differences in sensitivity to behavioral integrity: attitudinal consequences, in-group effects, and" trickle down" among Black and non-Black employees. Journal of Applied Psychology, 92(3), 650.

Sikes, B., Gulbro, R. D., \& Shonesy, L. (2010). Conflict in work teams: problems and solutions. In Allied Academies International Conference. Academy of Organizational Culture, Communications and Conflict. Proceedings (Vol. 15, No. 1, p. 48). Jordan Whitney Enterprises, Inc.

Somech, A., Desivilya, H. S., \&Lidogoster, H. (2009). Team conflict management and team effectiveness: The effects of task interdependence and team identification. Journal of Organizational Behavior: The International Journal of Industrial, Occupational and Organizational Psychology and Behavior, 30(3), 359-378.

Speakman, J., \& Ryals, L. (2010). A re-evaluation of conflict theory for the management of multiple, simultaneous conflict episodes. International Journal of Conflict Management, 21(2), 186-201.

Tekleab, A. G., Quigley, N. R., \&Tesluk, P. E. (2009). A longitudinal study of team conflict, conflict management, cohesion, and team effectiveness. Group \& Organization Management, 34(2), 170-205.

Thomas, K. W. (1992). Conflict and negotiation processes in organizations.

Tidd, S. T., McIntyre, H. H., \& Friedman, R. A. (2004). The importance of role ambiguity and trust in conflict perception: Unpacking the task conflict to relationship conflict linkage. International Journal of Conflict Management, 15(4), 364-380.
Tjosvold, D. (2002). Cooperative goals and constructive controversy for promoting innovation in student groups in China. Journal of Education for Business, 78(1), 46-50.

Townsley, C. A. (2009). Resolving conflict in work teams. Retrieved July 8, 2011, from Team Building Directory: http://www.innovativeteambuilding.co.uk/pages/articles/confli cts.htm.

VanWoerkom, M., \& Croon, M. (2009). The relationships between team learning activities and team performance. Personnel Review, 38(5), 560-577.

Wall Jr, V. D., \& Nolan, L. L. (1986). Perceptions of inequity, satisfaction, and conflict in task-oriented groups. Human Relations, 39(11), 1033-1051.

Watson, W. E., Johnson, L., \& Merritt, D. (1998). Team orientation, self-orientation, and diversity in task groups: Their connection to team performance over time. Group \& Organization Management, 23(2), 161-188.

Watson, W., Cooper, D., Torres, M. J. L. N., \& Boyd, N. G. (2008). Team processes, team conflict, team outcomes, and gender: An examination of US and Mexican learning teams. International Journal of Intercultural Relations, 32(6), 524-537.

Wall Jr, J. A., \& Callister, R. R. (1995). Conflict and its management. Journal of Management, 21(3), 515-558.

Wageman, R., Hackman, J. R., \& Lehman, E. (2005). Team diagnostic survey: Development of an instrument. The Journal of Applied Behavioral Science, 41(4), 373-398.

West, M., Borrill, C. A., \&Unsworth, K. L. (1998). Team effectiveness in organizations.

Wilson, J. M., \& Goodman, P. S. (2007). Cronin M A. Group learning, 32, 1041-1059.

Wickramasinghe, V., \&Nandula, S. (2015). Diversity in team composition, relationship conflict and team leader support on globally distributed virtual software development team performance. Strategic Outsourcing: An International Journal, 8(2/3), 138-155. 